\title{
ASPECTS OF PERMIAN PALAEOBOTANY AND PALYNOLOGY. V. ON THE NATURE OF ASTEROPHYLLITES DUMASII ZEILLER, ITS CORRELATION WITH CALAMITES GIGAS BRONGNIART AND THE PROBLEM CONCERNING ITS STERILE FOLIAGE
}

\section{J.H.F. KERP}

Laboratory of Palaeobotany and Palynology, State University, Heidelberglaan 2, 3508 TC Utrecht (The Netherlands)

(Received January 17, 1984; revised version accepted April 2, 1984)

\section{ABSTRACT}

Kerp, J.H.F., 1984. Aspects of Permian palaeobotany and palynology. V. On the nature of Asterophyllites dumasii Zeiller, its correlation with Calamites gigas Brongniart and the problem concerning its sterile foliage. Rev. Palaeobot. Palynol., 41: 301-317.

On the basis of abundant material from the Waderner Gruppe (= Nahe Gruppe of Boy and Fichter, 1982; Autunian, Lower Permian) of Sobernheim (Nahe area, southwest Germany) it can be demonstrated that the presumed sterile foliage Asterophyllites dumasii Zeiller only represents the bract-bearing axes of the strobilus Calamostachys dumasii (Zeiller) Jongmans. Pith casts and ou ter surface of Calamites gigas Brongniart - the stem correlated with Calamostachys dumasii - are described and figured. The problem concerning the sterile foliage of Calamites gigas is discussed. It is here proposed that Annularia carinata (Gutbier) Schimper might represent the sterile foliage of Calamites gigas.

\section{ZUSAMMENFASSUNG}

An Hand reich-haltiges Materials aus der Waderner Gruppe ( $\approx$ Nahe Gruppe von Boy und Fichter, 1982; Autunium, Unter Perm) von Sobernheim konnte nachgewiesen werden, dass die bisher als sterile Beblätterung interpretierte Art Asterophyllites dumasii Zeiller in Wirklichkeit brakteentragende Strobilusachsen von Calamostachys dumasii (Zeiller) Jongmans darstellt. Steinkerne und Oberflächen von Calamites gigas Brongniart - der Stamm mit dem Calamostachys dumasii korreliert wird - werden beschrieben und abgebildet. Es wird argumentiert, dass Annularia carinata (Gutbier) Schimper die sterile Beblätterung von Calamites gigas sein könnte.

\section{INTRODUCTION}

The species Asterophyllites dumasii was established by Zeiller (1892) for some specimens originating from Autunian (Lower Permian) strata of Gourd du Diable (Brive Basin, France). Both sterile and fertile material, presumed to have belonged to the same plant, was described under this name. The fertile material was transferred by Jongmans (1911) to the genus Calamostachys Weiss. This resulted in the combination Calamostachys dumasii (Zeiller) Jongmans. 
Calamostachys dumasii initially seemed to be a rather uncommon species in the Early Permian floras of Europe, but in the last ten years several additional localities have yielded the species. Besides in the type locality, C. dumasii is known from Moravia (C.S.S.R.; Augusta, 1947), Saxony (G.D.R.; Barthel et al., 1975; Barthel, 1976), Thuringia (G.D.R.; Barthel, 1980; Barthel and Kozur, 1981) and the Nahe area (G.F.R.; Kerp, 1982). Asterophyllites dumasii, which is believed to represent the sterile foliage of the same plant, has been mentioned from the Decazeville Basin (France; Bergounioux and Doubinger, 1943), the Brive Basin (France; Zeiller, 1892), Moravia (C.S.S.R.; Augusta, 1926, 1957, 1951), Saxony (G.D.R.; Barthel, 1976), Thuringia (G.D.R.; Barthel, 1980, 1982) and the Nahe area (F.R.G.; Kerp, 1982). The stratigraphic range of both species seems to be restricted to the Autunian.

Speculations on the relationship between Calamostachys dumasii and Asterophyllites dumasii were based on similarities in the shape of the bracts and the sterile leaves and on their co-occurrences. However, up to the present time this presumed relationship could not satisfactorily be proved.

In the present paper new material from the Lower Permian of Sobernheim is described and a selection of the available material is figured.

\section{DEDICATION}

This paper is dedicated to the memory of Dr. S.J. Dijkstra, who carried out an immense task in continuing Jongmans' Fossilium Catalogus II, Plantae; he was a pioneer in megaspore stratigraphy and contributed important knowledge to the natural history of the Dutch province of Limburg.

\section{MATERIAL, SOURCE STRATA AND METHODS}

The material under investigation was collected in the "Ziegelei Eimer" brick-pit at Sobernheim (Nahe area, F.R.G.), where red clay- and siltstones with some grey-green plant-bearing intercalations are excavated. During the past five years the present author has studied the rich megaflora, which has an Autunian (Early Permian) age (Kerp, 1982).

Calamostachys dumasii is a very common species in the fossil flora of Sobernheim. Isolated strobili are frequently found and specimens showing a preservation with strobili still attached to axes are rather common, whereas the presumed sterile foliage (Asterophyllites dumasii) appears to be rather rare.

The material is preserved as compressions/impressions. Due to the bad state of preservation the anatomy could not be studied. The material under investigation is stored in the following collections:

(a) Collection of the Laboratory of Palaeobotany and Palynology, Utrecht. In this paper collection numbers are preceded by the letter $U$.

(b) Collection of the "Sektion Paläobotanik" of the Forschungsinstitut Senckenberg, Frankfurt am Main. Collection numbers are preceded by the letter B. 
(c) Private collection of Mr. K. Baum, Sobernheim.

The photographs were made with polarized light. In some cases a combination of polarized light and alcohol was used in order to obtain the necessary contrasts.

\section{DESCRIPTION}

Calamostachys dumasii (Zeiller) Jongmans and Asterophyllites dumasii Zeiller (Plates I-IV)

The strobili of Calamostachys dumasii are attached to axes (Plate I, Plate II, Plate III, 1, 4). The axes vary in width from 2 to at least $22 \mathrm{~mm}$. Nodes are situated at distances of 2 to $42 \mathrm{~mm}$. The length of the internodes decreases apically, but not regularly. Nodal lines are mostly indistinct. The ribs are not prominent, $0.3-0.5 \mathrm{~mm}$ wide, with a delicate longitudinal striation. A number of ribs do not alternate at the nodes, but the ribs pass over the nodes. Otherwise the ribs terminate at the nodes with more or less rounded apices.

Six to eight (ten) strobili are attached at each node. Normally only a few strobili are visible, but scars on the axes (Plate I, 2) indicate their original number. Strobili vary in length from $4 \mathrm{~mm}$, in young and immature specimens, to at least $60 \mathrm{~mm}$; the width varies from 1.8 to 7 (average 4 ) $\mathrm{mm}$, including the bracts. Strobilus axes are up to $1 \mathrm{~mm}$ wide, with a faint longitudinal striation. Nodes are situated at distances of 0.7 to 2 (average 1.5) $\mathrm{mm}$. At each node six to eight bracts are attached, but mostly only two to four are visible. Bracts are narrow, 1.5 to $4 \mathrm{~mm}$ long, inserted at right angles to the strobilus axes or slightly raised apically.

A considerable variation in the shape of the bracts can be observed, even within a single specimen. Both narrow falcate bracts (Plate III, 3, 5, 7) and bracts set perpendicularly to the strobilus axis, strongly arching apically close to the axis (Plate III, 3), may occur. A thickening near the base of the bract may be present (Plate III, 1) as well as a "heel" on the lower surface of the bract (Plate III, 3, 7). The heel usually covers a part of the sporangium in the whorl below. The bracts generally extend to the middle of the superposed internode, however, in some cases they are longer and they may cover two internodes (Plate III, 3).

The detailed morphology of the strobili is not well known. Usually the sporangiophores can not be observed. Plate III, 5 shows that the sporangiophores are attached to the middle of the internodes. In this specimen the sporangiophores seem to be developed as so-called "rosendornförmigen Sporangiophoren"; in this case the sporangiophores should be connected with the bracts of the superposed verticil by a velum. The number of sporangia in a whorl cannot be determined. The sporangia are ovoid, up to $1.8 \mathrm{~mm}$ in diameter.

Thus far only sporangia-bearing strobili have been considered. However, in quite a number of specimens (a part of) the sporangia have become detached. This can be demonstrated in isolated strobili (Plate III, 2, 8) and in strobili 
still in organic connection with an axis (Plate II, Plate III, 1, 4). In the specimens figured on Plate II some of the strobili are only partially dissporangiated $^{1}$, whereas others have lost their sporangia completely. The sporangia are detached first in the basal part of the strobilus (Plate II, 1, 3, Plate III, 1, 4, 8 ). However, there is one specimen with only the middle part of the strobilus dissporangiated (Plate III, 2). This, however, might be explained as damage, because the bracts are absent as well. Within a compound system of a strobilibearing axis, the strobili of the apical part seem to dissporangiate first (Plate II, 1, 3).

The bracts of the dissporangiated (parts of the) strobili are similar to those of the sporangia-bearing ones. However, there exists a remarkable difference in length between the internodes of the dissporangiated and the sporangiabearing parts of the strobili. The length of a dissporangiated internode can be up to three times the length of a sporangia-bearing internode. Thus, a strobilus considerably increases in length during its maturation.

The presumed sterile foliage, Asterophyllites dumasii, is identical with the entirely dissporangiated strobili. Some examples are figured on Plate IV. Also here a variability in the shape of the bracts can be demonstrated; narrow falcate bracts (Plate IV, 6), or strongly arched bracts (Plate IV, 4), with a basal thickening (Plate IV, 6) or a heel near the attachment to the strobilus axis (Plate IV, 4) occur.

Calamites gigas Brongniart (Plate V, Plate VI, 1, 2)

Calamites gigas is frequently to be found at Sobernheim and includes specimens up to $20 \mathrm{~cm}$ wide and $1.20 \mathrm{~m}$ long. Characteristic are the short internodes, rarely longer than broad, with ribs up to $1 \mathrm{~cm}$ wide. The ribs alternate at the nodes, but they can also pass over the nodes (Plate $V, 2$ ). The alternating ribs terminate in prolonged acute points (Plate V, 2, Plate VI, 2). In a number of specimens oval tubercles are to be seen at the endings of the ribs (Plate VI, 1, 2). According to the descriptions of several authors (e.g., Kidston and Jongmans, 1917; and Boureau, 1964), these tubercles should be characteristic. Mostly, however, they are very difficult to observe, especially on impressions. Considerable variability in the shape of the ribs can be observed, even within a single specimen (see, e.g., Plate V, 2). The nodal lines are not always distinct. Branched stems and stems with branch scars have so far not been found at Sobernheim.

\footnotetext{
${ }^{1}$ Dissporangiation: a term introduced to define the release of complete sporangia; analogue to dissemination.

\section{PLATE I}

Calamostachys dumasii (Zeiller) Jongmans

1. Axis with strobili. Specimen U 4198. $\times 0.75$.

2. Axis with young and immature strobili. Note the scars on the axis where the strobili are detached. Specimen U 13160. $\times 2$.

3. Axis with strobili. The most robust one collected at Sobernheim. Specimen U 8373. $\times 1$.
} 


\section{PLATE I}
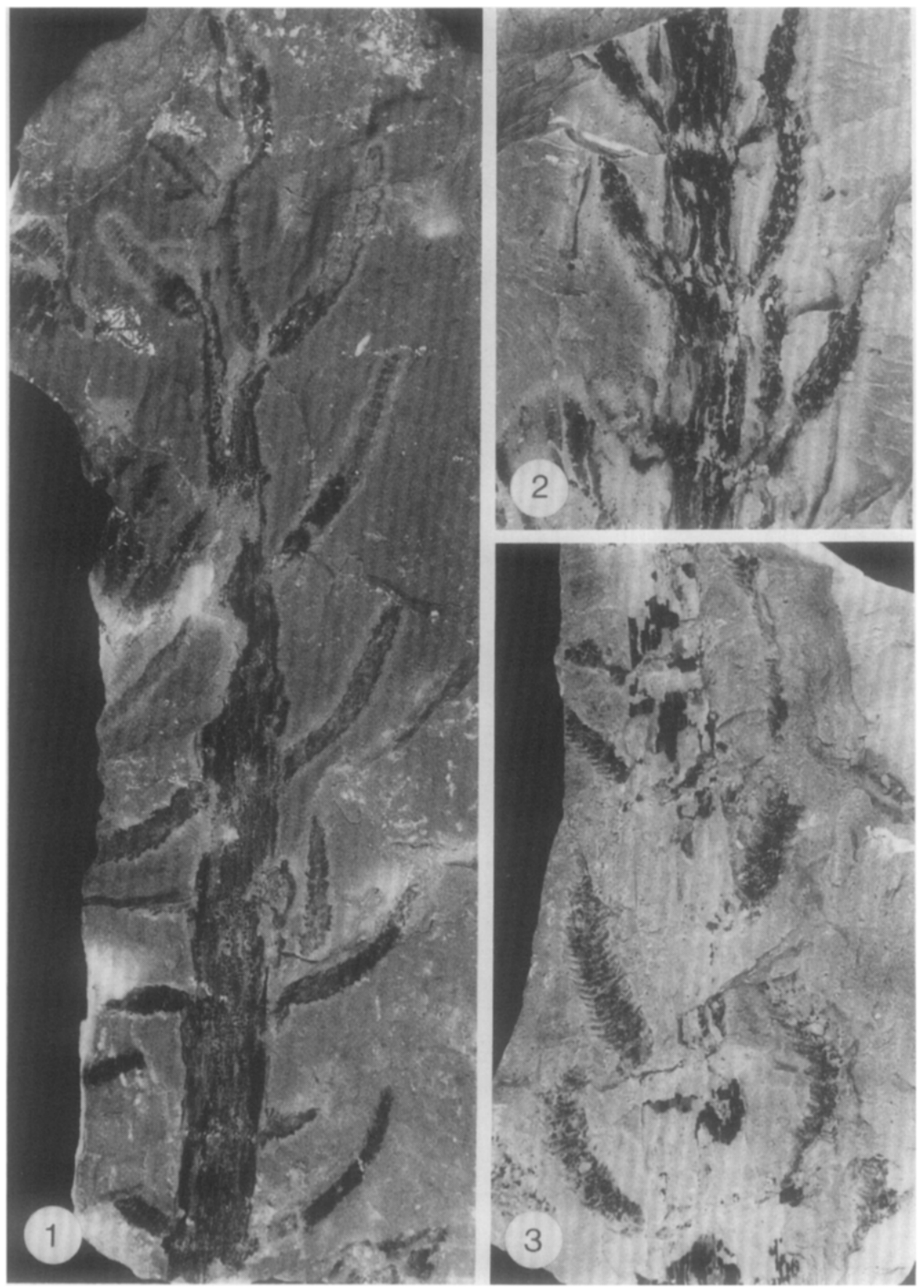


\section{PLATE II}
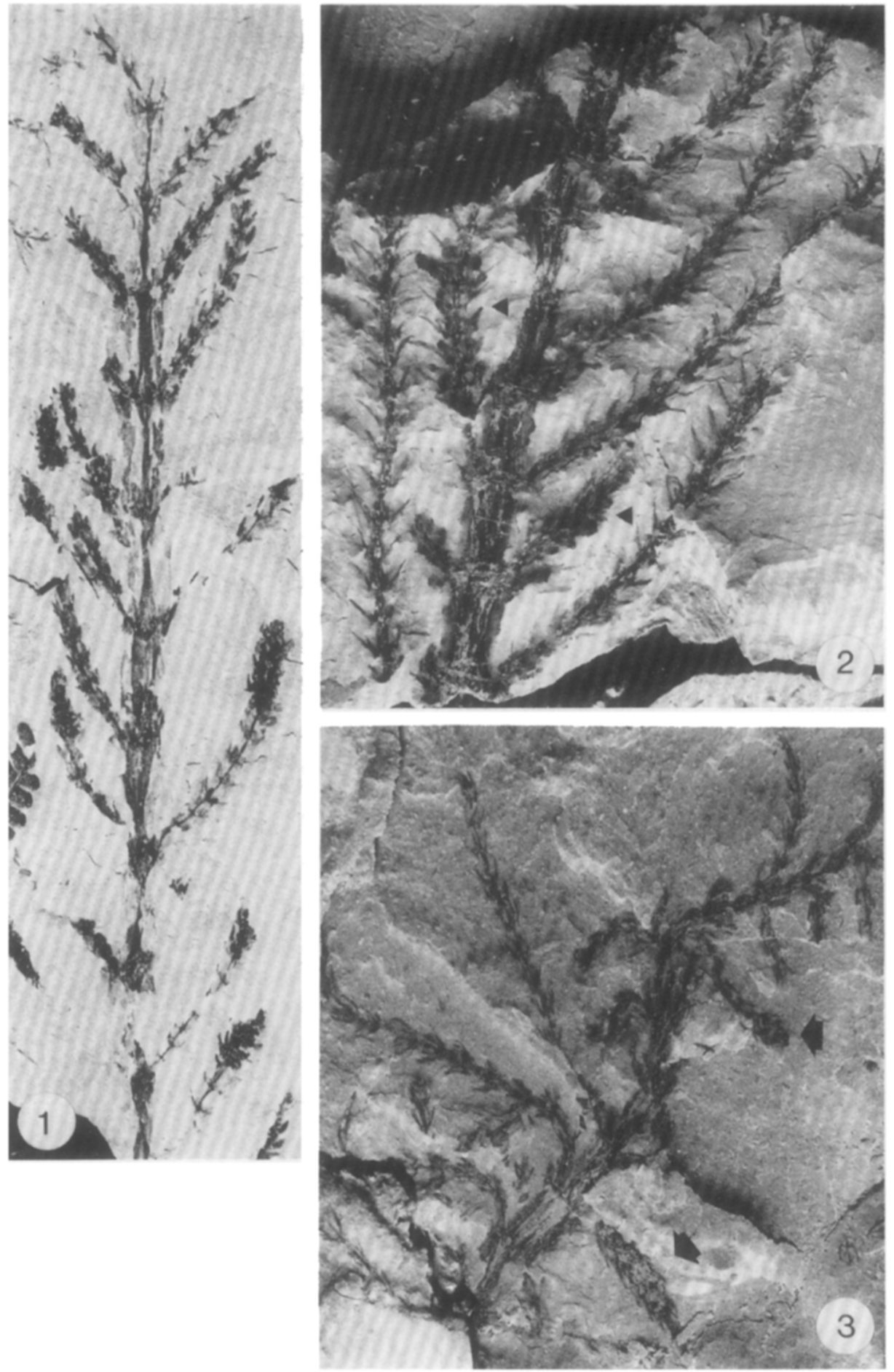
A newly discovered feature of $C$. gigas is the outer surface of the stem. Thus far only pith casts have been known. In some of the Sobernheim specimens, impressions of the outer surface are preserved around the flattened pith casts (Plate V, 1). The outer surface sometimes shows a faint ribbing, not corresponding with the ribs of the pith cast. The outer surface is irregularly wrinkled. The nodal lines are irregular and quite indistinct.

Apart from outer surfaces of calamitalean stems still situated around the pith casts, also isolated parts of outer surfaces have been found. However, the lack of distinguishing characters makes the recognition of these isolated parts of outer surfaces very difficult.

\section{DISCUSSION}

Although the material of Calamostachys dumasii is not preserved in all features, it appears that the sporangiophores are situated near the middle of the internodes. This justifies the classification within the genus Calamostachys. For the first time the presence of so-called "rosendornförmigen Sporangiophoren" is observed in Calamostachys dumasii. Barthel (1976) gave a description of similar structures in $C$. tuberculata. This structure, which was earlier interpreted as an undeveloped sporangium (Zeiller, 1886), appeared to be a phylloid tissue, which initially was fused with the sporangiophore and the superposed sterile bract.

In the compression/impression form of preservation, calamitalean strobili are occasionally found attached to stems and foliage. For structurally preserved isolated material from coal balls, Good (1975) used three criteria to suggest natural relationships among isolated calamitalean plant parts: (1) cooccurrences of the different plant parts; (2) similarities in the anatomy of rays and radial pitting of strobilus axes, peduncles and stems; and (3) similarities in morphology and anatomy of vegetative leaves and bracts. For isolated strobili and vegetative leaves in compression/impression material, cooccurrences and similarities in morphology of bracts and vegetative leaves are used to suggest natural relationships.

Zeiller (1892) noted the presence of two successive "sterile" verticils at the base of the strobilus of $C$. dumasii. The specimens figured by Barthel (1976, pl. 27, 2, 3) do not show these sterile verticils. Barthel noticed that the sterile foliage of Asterophyllites dumasii was only sporadically found in Saxony, whereas the strobilus $C$. dumasii appears to be much more common.

\section{PLATE II}

Calamostachys dumasii (Zeiller) Jongmans

1. Axis with strobili. The strobili are partly or completely dissporangiated. Specimen B 13477. $\times 1.4$.

2. Axis with strobili, mostly dissporangiated. The arrows indicate strobili still holding sporangia. Specimen U 13162. $\times 2$.

3. Axis with dissporangiated strobili. Only two strobili still bear sporangia (arrows). Specimen U 13161. $\times 2$. 


\section{PLATE III}
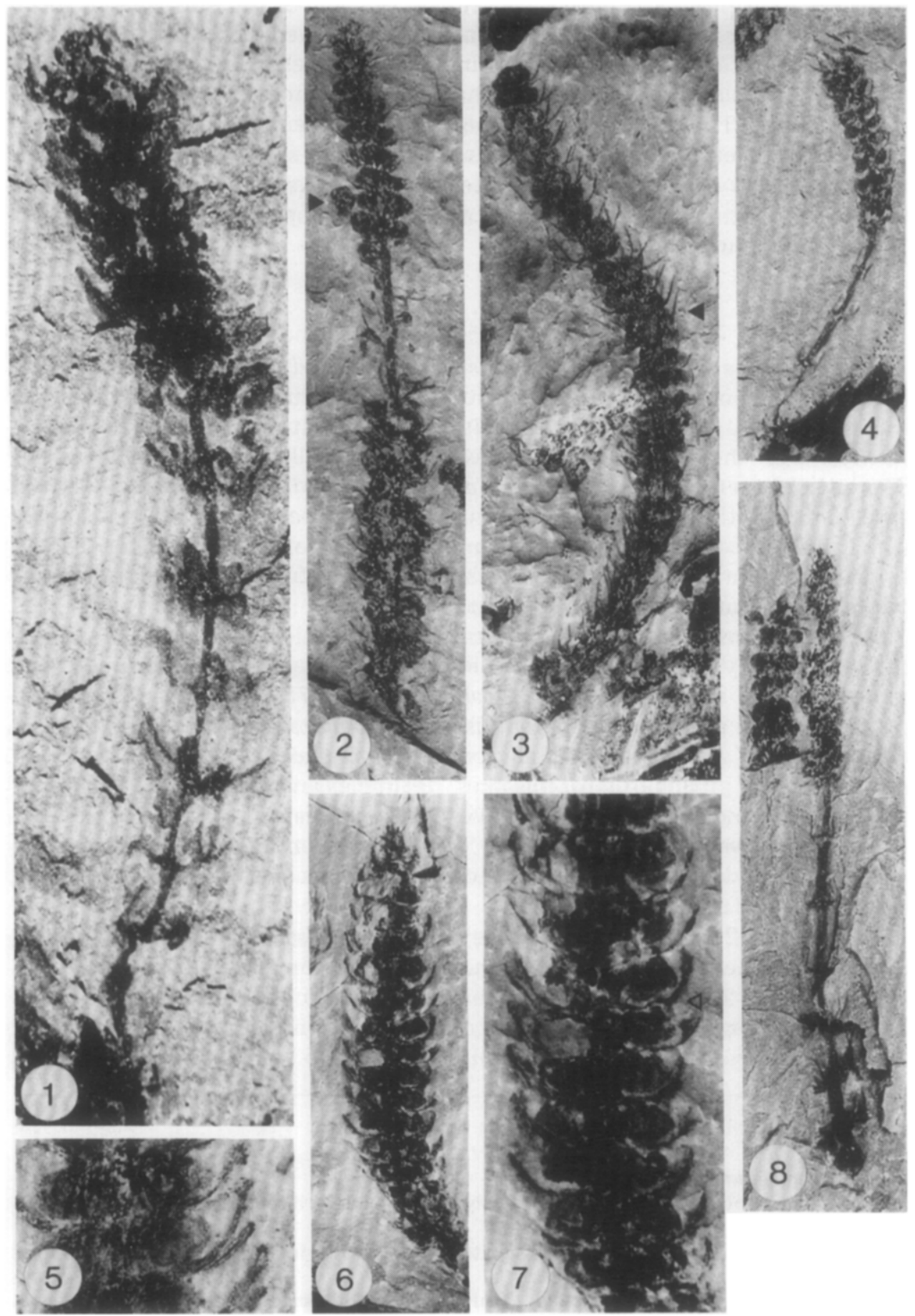
The surprising similarities between the foliage A. dumasii and the bracts of the strobilus $C$. dumasii gave Barthel (1976) reasons to question the sterile nature of $A$. dumasii. Barthel's opinion was furthermore supported by cooccurrences with a small type of Annularia (Barthel, 1976, pl. 27, 14). But on the other hand, the existence of long Asterophyllites dumasii twigs (Zeiller, 1892; Augusta, 1926, 1947) convinced him of the sterile nature of this taxon.

The observations above leave little doubt that Asterophyllites dumasii Zeiller sensu Jongmans (1911) represents only a dissporangiated type of strobilus, which in an earlier ontogenetic stage is known as Calamostachys dumasii (Zeiller) Jongmans. Therefore, the name Asterophyllites dumasii has to be considered as a synonym.

Apparently the strobili continued to grow in longitudinal direction during and/or after the release of the sporangia. Isolated sporangia of C. dumasii are rather common in the Sobernheim material (Plate III, 2). Also Barthel (1980, pl. 95, 8) figured a mass of detached sporangia. The elongation of the strobilus axis during the final stage of maturation, as in the living genus Equisetum, is now recorded from Late Palaeozoic equisetalean strobili of the Calamostachys type (see Gastaldo, 1981, p.1322). Therefore, delimiting criteria for Palaeozoic equisetalean strobili, such as the length of the internodes, have to be treated with care.

It is remarkable that so many dissporangiated strobili of $C$. dumasii have been found still attached to the axes. In other species, such as $C$. tuberculata, the mature strobili usually have become detached. After their reproductive function, the dissporangiated strobili possibly served as assimilation organs.

Augusta (1926) described Asterophyllites dumasii var. moravicus. The distinctive characters include small differences in size, and small variations in the number of strobili attached to a node and the number of leaves (= bracts) in a verticil. The Sobernheim material shows that Augusta's specimens completely fit within the natural variability of $C$. dumasii, and that there was no reason to establish a separate variety of this species.

Asterophyllites dumasii was placed in a group together with e.g., $A$. grandis (Sternberg) Geinitz and A. charaeformis (Sternberg) Unger on

PLATE III

Calamostachys dumasii (Zeiller) Jongmans

1. Detail of Plate II, 1. Partly dissporangiated strobilus. $\times 5$.

2. Isolated strobilus, middle part dissporangiated. The arrow indicates a detached sporangium. Specimen U 13305. $\times 2$.

3. Isolated strobilus with extremely long bracts. The arrow indicates a strongly arched bract with a "heel" on the abaxial side. Specimen U 13306. $\times 2$.

4. Strobilus attached to an axis, basal part dissporangiated. Specimen B 13478. $\times 2$.

5. Detail of an isolated strobilus showing narrow falcate bracts and the position of the sporangiophore (rosendornförmigen Sporangiophore). Specimen U 6809. $\times 7$.

6. Apical part of an isolated strobilus. Specimen U 6842A. $\times 3.1$.

7. Detail of Plate III, 6 showing the organization of the strobilus. The arrow indicates a "heeled" bract. $\times 7.5$.

8. Isolated strobilus, basal part dissporangiated. Specimen U 9363A. $\times 2$. 


\section{PLATE IV}
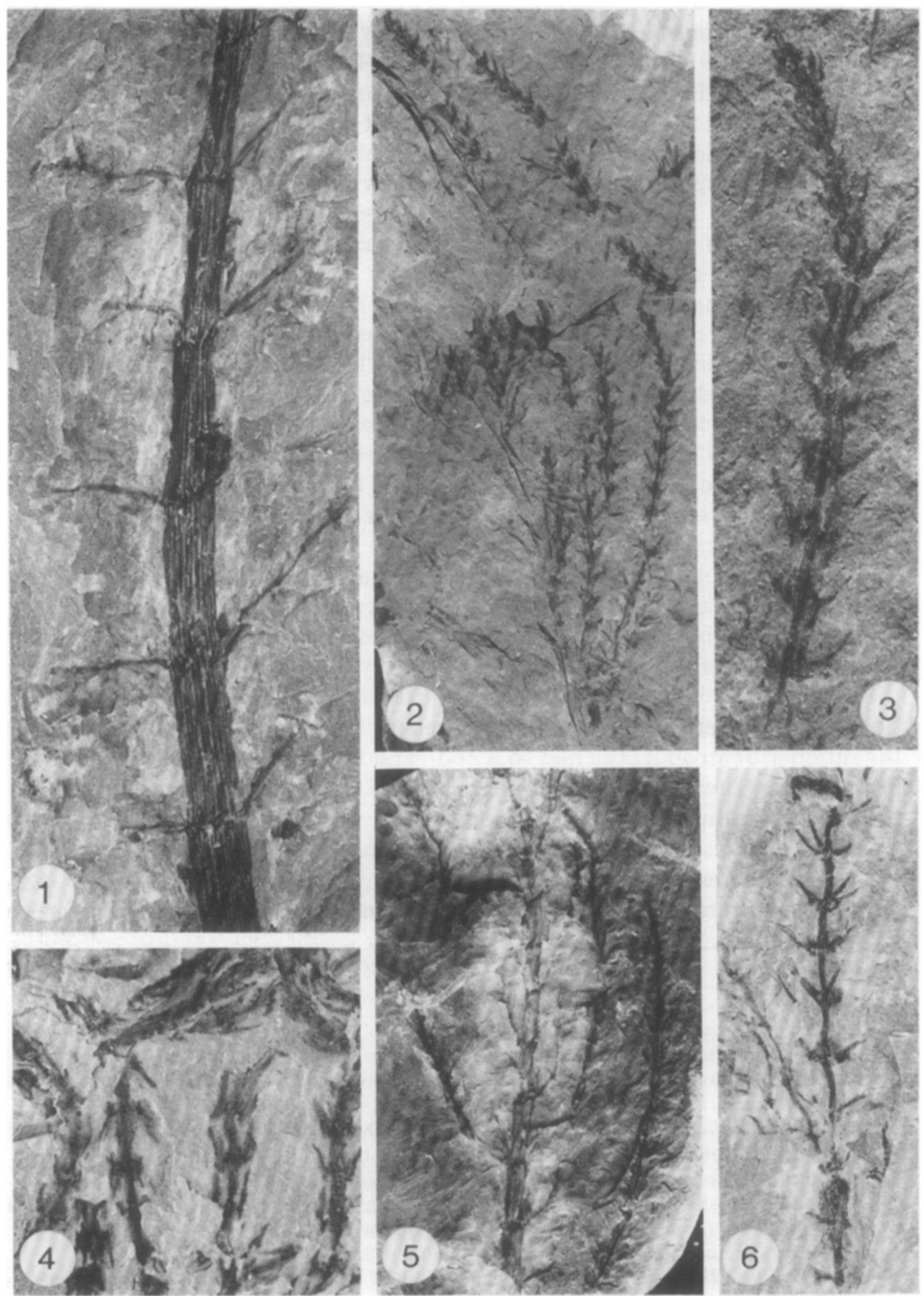
grounds of similarities in morphology (Jongmans, 1911). Especially the fructification of Asterophyllites grandis (= Calamostachys tenuifolius Ettingshausen) shows a remarkable similarity in the shape of the bracts with the sterile foliage. On the basis of the present knowledge of $C$. dumasii, it might be suggested that similar dissporangiation processes could also take place in other calamitalean strobili.

\section{The stems correlated with Calamostachys dumasii}

In his original description of Asterophyllites dumasii, Zeiller (1892) mentioned Calamites gigas as the type of stem correlated with Calamostachys dumasii. This suggestion was based on co-occurrences. Although these two species were never found in organic connection, this speculation was supported by subsequent authors who mentioned close associations in a number of localities (Bergounioux and Doubinger, 1943; Augusta, 1947, 1951; Barthel et al., 1975; Barthel, 1976, 1980, 1982). Also at Sobernheim, these species are always found in close association, which seems to favour the suggested relationship. In this context Kornkiste, another locality in the Saar-Nahe area, also has to be mentioned. At Kornkiste, near Schallodenbach (Schuster, 1908), Calamites gigas and Calamostachys dumasii have recently been found together. In addition, in an assemblage recently discovered near Zella-Mehlis (Thuringia, G.D.R.) these species are recorded from a qualitatively very poor flora in which they appear to be the only calamitalean elements (Barthel and Kozur, 1981).

\section{Problems concerning possible sterile foliage of Calamites gigas}

Now that it has been demonstrated above that Asterophyllites dumasii represents the dissporangiated strobilus Calamostrachys dumasii instead of a type of sterile foliage, a new problem arises. What kind of sterile foliage may be attributed to Calamites gigas, if this plant had sterile foliage?

Barthel (1976) mentioned small Annularia species occurring together with Calamites gigas in the Döhlener Basin (G.D.R.). The verticils hold about 16 equally sized leaves. Only a single incomplete specimen was figured which could not be identified as any known species. Because Barthel's material is not very characteristic, it allows no comparison with Annularia species from Sobernheim.

\section{PLATE IV}

Calamostachys dumasii (Zeiller) Jongmans

1. Axis with basal parts of dissporangiated strobili. Specimen U 9363A. $\times 1.5$.

2. Several dissporangiated strobili. Specimen B 13476A. $\times 1$.

3. Detail of Plate IV, 2. $\times 5$.

4. Dissporangiated strobili with strongly arched bracts. Specimen U $8379 . \times 2$.

5. Axis with several completely dissporangiated strobili. Specimen U 13159B. $\times 1$.

6. Isolated dissporangiated strobili with narrow falcate bracts (apically) and bracts with a basal thickening. Specimen U 9363A. 


\section{PLATE V}
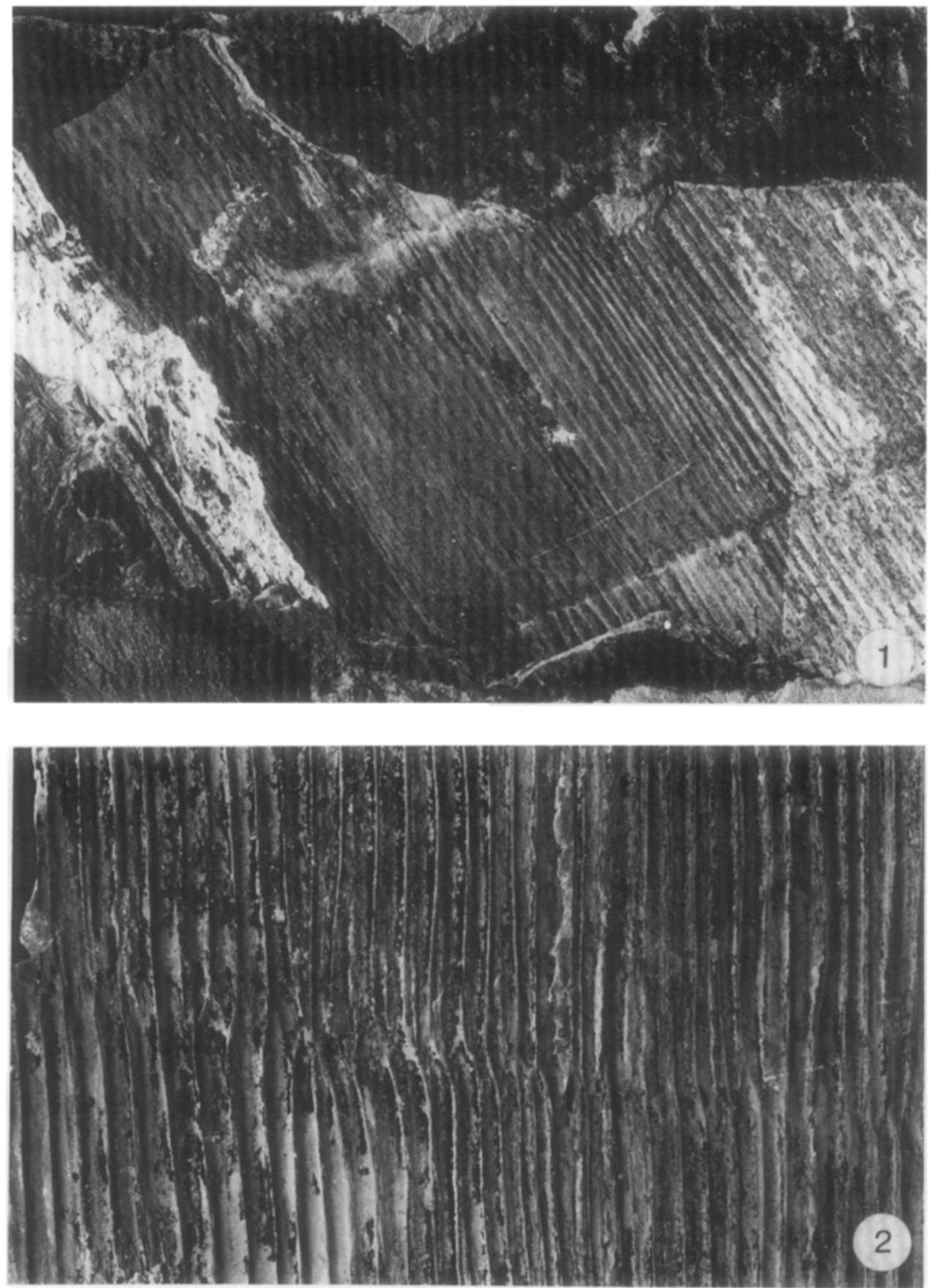
From Sobernheim three species of calamitalean foliage are known, viz. Annularia spicata (Gutbier) Schimper, A. stellata (Schlotheim) Wood and A. carinata Gutbier. A. spicata, a rather common species in the Sobernheim flora, can be correlated with certainty with Calamostachys spicata (Remy and Remy, 1975). A. stellata is known to belong to Calamostachys tuberculata, also to be found at Sobernheim. Of the three species of calamitalean foliage occurring at Sobernheim, A. carinata is the one that is found most frequently.

The most characteristic feature of Annularia carinata (Plate VI, 3, 4), a species originally described from Zwickau-Reinsdorf (Von Gutbier, 1849), is the anisophylly of the verticils. Each verticil possesses 8-18 leaves. The leaves are up to $24 \mathrm{~mm}$ long and the vein is very prominent, whereas the lamina appears to have been very thin.

Annularia carinata is a species often neglected in the literature. It was considered as a synonym of $A$. stellata (Zeiller, 1906; Jongmans, 1911) or even as a synonym of Asterophyllites equisetiformis (Potonié, 1893). Indeed, Annularia carinata can easily be confused with $A$. stellata. However, the latter has more (up to 30 ) and longer leaves in a verticil. Small verticils of $A$. carinata may even be confused with Annularia sphenophylloides. Specimens of $A$. carinata have been mentioned with certainty in the literature as being A. stellata. Barthel (1976) identified specimens figured by De Stefani (1901) and Augusta (1947) as A. carinata.

The Sobernheim material of $A$. carinata (Plate VI, 3,4 ) is very similar to Von Gutbier's type material, but larger, $A$. carinata-bearing stems have hitherto not been found. As was stated above, it is the most common type of calamitalean foliage in the Sobernheim locality, whereas Calamostachys dumasii is the most common type of calamitalean fructification there. These two species were often found in close association. Sometimes the bedding planes are covered exclusively with Calamostachys dumasii and Annularia carinata. For Sobernheim this might suggest a relationship between these two species; however, no organic connections are known. Probably comparisons of leaf-bearing Annularia carinata axes as figured by Von Gutbier (1849), with Calamostachys dumasii-bearing axes could further support this suggestion. However, thicker $A$. carinata-bearing axes are not known from Sobernheim and Von Gutbier's plate II, 4-7 (1849) does not show enough details. The knowledge on co-occurrences in other localities is insufficient, because Calamostachys dumasii has often been neglected, while Annularia carinata frequently has been identified as $A$. stellata.

\section{PLATE V}

Calamites gigas Brongniart

1. Pith cast partially covering the impression of the outer surface of the stem (dark imprint on the upper part of the photograph). Specimen U 13780. $\times 1$.

2. Nodal line of a pith cast. Note the irregularity in the "alternation" of the ribs. Specimen U $13729 . \times 1$. 


\section{PLATE VI}
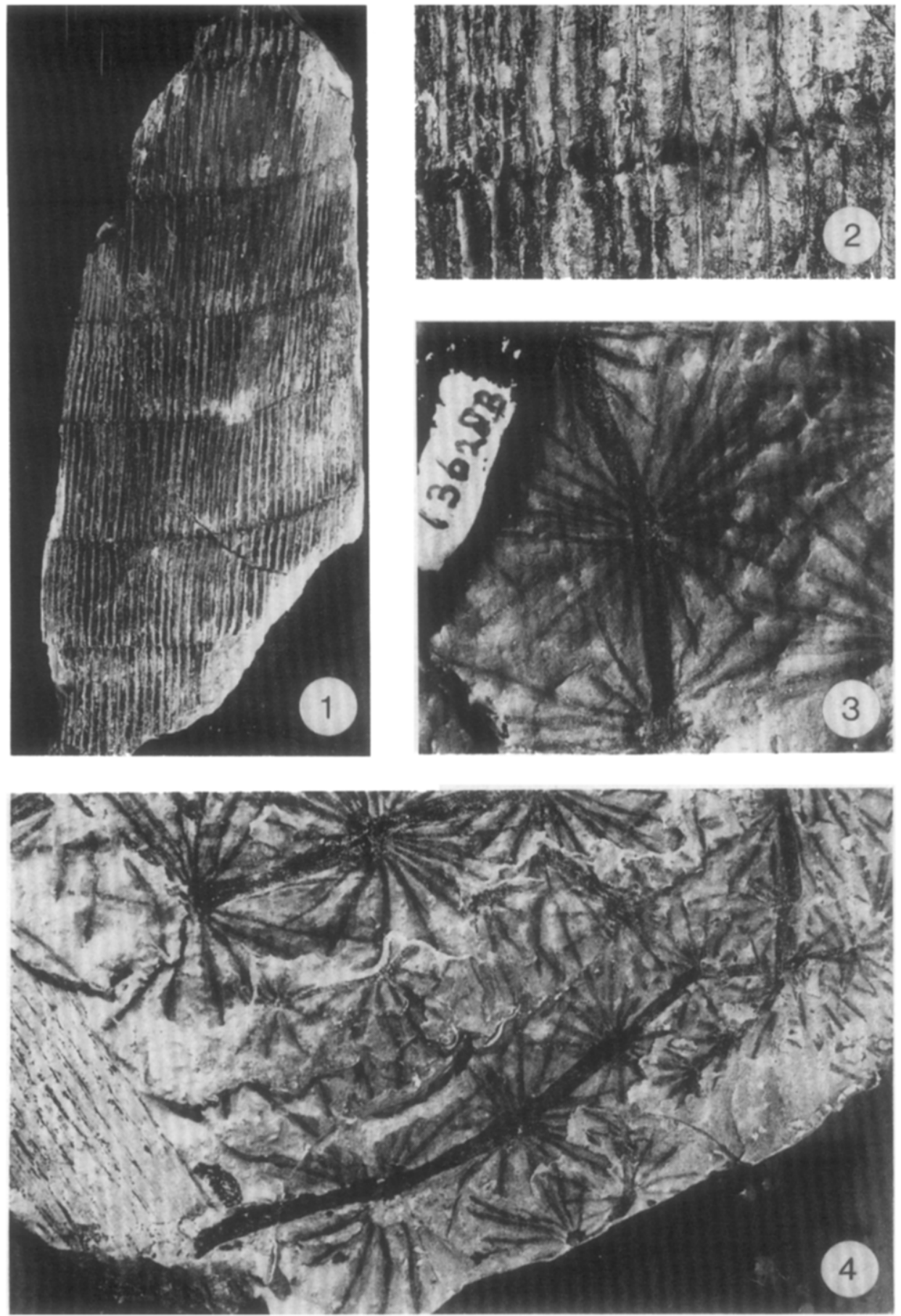
From Weissig (Saxony, G.D.R.) a small Calamostachys tuberculata-like strobilus is known, which has been attributed to Annularia carinata. However, only a single badly preserved fragment, not showing essential details, has been figured (Barthel, 1976, pl. 26, 13).

\section{Some considerations with regard to the reconstruction of Calamites gigas}

Leistikow $(1962,1975)$ and Barthel $(1976,1980)$ have demonstrated that the stems of Calamites gigas were growing free instead of arising from rhizomes. An orthotropic primary root of $C$. gigas has been figured by Barthel $(1980$, pl. 95, 7, 1982, fig.41). C. gigas is the only known Early Permian freegrowing calamite, thus being a species with a rather exceptional growth habit. The lack of rhizome excludes the possibility of vegetative reproduction, which explains the huge amount of strobili to be found.

Branch scars were only rarely found in C. gigas; Barthel $(1980, \mathrm{pl} .95,6)$ figured a single specimen. He (1982) suggested that the small Calamostachys dumasii- and "Asterophyllites dumasii"-bearing stems could well represent young stems of Calamites gigas, instead of being secondary branches.

However, up to the present time the knowledge of Calamites gigas and its correlated organs is still unsatisfactory. Only further collecting, e.g. at Sobernheim where this plant is a prominent constituent of the megaflora, can yield more complete material which may lead to a better understanding of this rather exceptional species of the genus Calamites.

\section{ACKNOWLEDGEMENTS}

The author wishes to thank Prof. Dr. H. Visscher and Dr. M. Boersma for critically reading the manuscript. He gratefully acknowledges the help of Mr. H. Eimer and Mr. K. Baum (Sobernheim) by providing the collecting facilities as well as their sincere interest in the investigations. Thanks are due to Dr. F. Schaarschmidt (Frankfurt a/M.) for hospitality during the stay at "Senckenberg" and for placing the material stored in the collections of this institute at his disposal. Thanks are extended to Mr. H. A. Elsendoorn for preparing the photographs.

The investigations were supported by the Netherlands Foundation for Earth Science Research (AWON) with financial aid from the Netherlands Organization for the Advancement for Pure Research (Z.W.O.).

\section{PLATE VI}

Calamites gigas Brongniart

1. Pith cast with six nodes. Specimen U 13960. $\times 0.25$.

2. Detail of Plate VI, 1 showing the tubercles on the endings of the ribs. Note the irregularity in the alternation.

Annularia carinata Von Gutbier

3. A single verticil clearly showing the anisophylly. Specimen 13628B. $\times 4$.

4. Some leafy branches. Specimen U 13155. $\times 2$. 


\section{REFERENCES}

Augusta, J., 1926. "Asterophyllites dumasi Zeiller var. moravicus nov. var." du Permien de la Fosse de Boskovice. Publ. Fac. Sci. Univ. Masaryk, 79: 1-12 (in Czech with French summary).

Augusta, J., 1947. The Lower Permian fauna and flora of a new locality behind the sawmill of the "Antonin" Mine at Zbýšsov in Moravia. Véstn. Státniho. Geol. Ústavu. Cesk. Republ., 22: 187-224 (in Czech with English summary).

Augusta, J., 1951. Flora of the Lower Permian in the farther area of the coal basin of Rosice-Oslavany in Moravía (Czechoslovakia). Sb. Ust. Geol. C. S. R., 18: 397--424 (in Czech with English summary).

Barthel, M., 1976. Die Rotliegendflora Sachsens. Abh. Staatl. Mus. Mineral. Geol., Dresden, 24: $1-190$.

Barthel, M., 1980. Calamiten aus dem Oberkarbon und Rotliegenden des Thüringer Waldes. 100 Jahre Arboretum (1879-1979), Berlin, p.237-258.

Barthel, M., 1982. Die Pflanzenwelt. In: H. Haubold (Editor), Die Lebewelt des Rotliegenden. Die Neue Brehmbücherei 154, A. Ziemsen Verlag, Wittenberg, pp.63-131.

Barthel, M, and Kozur, H., 1981. Ein Callipteris-Vorkommen im Thüringer Wald. Freiberg. Forschungsh., C 363: 27-41.

Barthel, M., Mütze, K. and Simon, R., 1975. Neue Funde fossiler Pflanzen aus dem SaaleTrog. Wiss. Z. Humboldt Univ, Berlin, Math.-Nat. R., 24: 475-485.

Bergounioux, F.M. and Doubinger, J., 1943. Flore des découvertes de Decazeville. C.R. Acad. Sci. Paris, 21 7: 612-613.

Boureau, E., 1964. Traité de Paléobotanique. III. Sphenophyta, Noeggerathiophyta. Masson, Paris, 544 pp.

Boy, J.A. and Fichter, J., 1982. Zur stratigraphie des saarpfälzischen Rotliegenden (?OberKarbon-Unter-Perm; SW-Deutschland). Z. Dtsch. Geol. Ges., 133: 607-642.

De Stefani, C., 1901. Flore Carbonifere e Permiane della Toscana. Pubbl. Ist. Studi Superiori Pratici Perfezionamento Firenze, Sez. Sci. Fis. Nat., Firenze.

Gastaldo, R.A., 1981. Taxonomic considerations for Carboniferous coalified equisetalean strobili. Am. J. Bot., 68(10): 1319-1324.

Good, C.W., 1975. Pennsylvanian-age calamitean cones, elater-bearing spores and associated vegetative organs. Palaeontographica, Abt. B, 153(1-3): 28-99.

Jongmans, W.J., 1911. Anleitung zur Bestimmung der Karbonpflanzen West-Europas, I, Thallophyta, Equisetales, Sphenophyllales. Meded, Rijksopsporing Delfstoffen, 3: $482 \mathrm{pp}$.

Kerp, J.H.F., 1982. New palaeobotanical data on the "Rotliegendes" of the Nahe area (F.R.G.). Cour. Forsch.-Inst. Senckenberg, 56: 7-14.

Kidston, R. and Jongmans, W.J., 1917. A monograph of the Calamites of Western Europe. Flora of the Carboniferous of the Netherlands and adjacent regions, Vol. I. Meded. Rijksopsporing Delfstoffen, 7: $207 \mathrm{pp}$.

Leistikow, K.U., 1962. Die Würzeln der Calamitaceae. Thesis, University of Tübingen, $67 \mathrm{pp}$.

Leistikow, K.U., 1975. Ein Konzept der Equisetales-Phylogenie. Cour. Forsch.-Inst. Senckenberg, 13: 140-143.

Potonié, H., 1893. Die Flora des Rothliegenden von Thüringen. Abh. K. Preuss. Geol. Landesanst., N.F., 9(II): 298 pp.

Remy, R. and Remy, W., 1975. Zur Ontogenie der Sporangiophore von Calamostachys spicata var. eimeri n. var. und zur Aufstellung des Genus Schimperia n. gen. Argumenta Palaeobot., $4: 83-92$.

Schuster, J., 1908. Zur Kenntnis der Flora der Saarbrücker Schichten und des pfälzischen Oberrotliegenden. Geogn. Jahresh., 1907, 20: 183-243.

Von Gutbier, A., 1849. Die Versteinerungen des Rothliegenden in Sachsen. Arnoldische Buch handlung, Dresden and Leipzig, 32 pp. 
Zeiller, R., 1886-1888. Bassin houiller de Valenciennes. Description de la flore fossile. Ét. Gîtes Miner. France, Paris, 731 pp.

Zeiller, R., 1892. Bassin houiller et permien de Brive, Fasc. II, Flore fossile. Ét. Gîtes Miner. France, Paris, $132 \mathrm{pp}$.

Zeiller, R., 1906. Bassin houiller et permien de Blanzy et du Creusot. Fasc. II, Flore fossile. Ét. Gîtes Miner. France, Paris, 265 pp. 